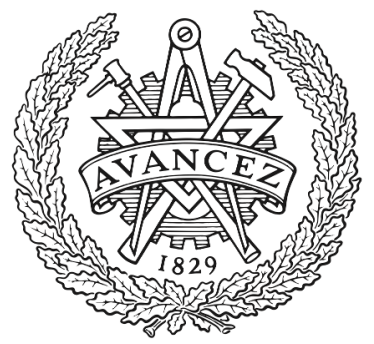

CHALMERS

UNIVERSITY OF TECHNOLOGY

\title{
Large-scale collective action to avoid an Amazon tipping point - key actors and interventions
}

Downloaded from: https://research.chalmers.se, 2023-04-26 12:47 UTC

Citation for the original published paper (version of record):

Bastos Lima, M., Harring, N., Jagers, S. et al (2021). Large-scale collective action to avoid an Amazon tipping point - key actors and interventions. Current Research in Environmental Sustainability, 3. http://dx.doi.org/10.1016/j.crsust.2021.100048

N.B. When citing this work, cite the original published paper. 


\title{
Large-scale collective action to avoid an Amazon tipping point - key actors and interventions
}

\author{
Mairon G. Bastos Lima ${ }^{\mathrm{a}, *}$, Niklas Harring ${ }^{\mathrm{b}}$, Sverker C. Jagers ${ }^{\mathrm{b}}$, Åsa Löfgren ${ }^{\mathrm{c}}$, \\ U. Martin Persson ${ }^{\mathrm{d}}$, Martin Sjöstedt ${ }^{\mathrm{b}}$, Bengt Brülde ${ }^{\mathrm{e}}$, David Langlet ${ }^{\mathrm{f}}$, Will Steffen ${ }^{\mathrm{g}}$, \\ Francisco Alpízar ${ }^{\mathrm{h}}$ \\ ${ }^{a}$ Stockholm Environment Institute, Box 24218, 10451 Stockholm, Sweden \\ ${ }^{\mathrm{b}}$ Center for Collective Action Research (CeCAR) and Department of Political Science, University of Gothenburg, Box 711, Sprängkullsgatan 19, 405 30 Gothenburg, \\ Sweden \\ ${ }^{c}$ Center for Collective Action Research (CeCAR) and Department of Economics, University of Gothenburg, Box 650, 40530 Gothenburg, Sweden \\ d Department of Space, Earth and Environment, Physical Resource Theory, Chalmers University of Technology, SE-412 96 Gothenburg, Sweden \\ ${ }^{\mathrm{e}}$ Center for Collective Action Research (CeCAR) and Department of Philosophy, Linguistics and Theory of Science, University of Gothenburg, Box 200, Olof Wijksgatan 6, \\ 41255 Gothenburg, Sweden \\ ${ }^{\mathrm{f}}$ Center for Collective Action Research (CeCAR) and Department of Law, Box 650, 40530 Gothenburg, Sweden \\ ${ }^{\mathrm{g}}$ Fenner School of Environment \& Society, The Australian National University, Building 141, Linnaeus Way, Canberra, ACT 2601, Australia \\ ${ }^{\mathrm{h}}$ Department of Social Sciences, Wageningen University and Research, P.O. Box 8130, 6700, EW, Wageningen, the Netherlands
}

\section{A R T I C L E I N F O}

\section{Keywords:}

Amazon

Tipping point

Deforestation

Large-scale collective action

Governance

Conservation policy

\begin{abstract}
A B S T R A C T
The destruction of the Amazon is a major global environmental issue, not only because of greenhouse gas emissions or direct impacts on biodiversity and livelihoods, but also due to the forest's role as a tipping element in the Earth System. With nearly a fifth of the Amazon already lost, there are already signs of an imminent forest dieback process that risks transforming much of the rainforest into a drier ecosystem, with climatic implications across the globe. There is a large body of literature on the underlying drivers of Amazon deforestation. However, insufficient attention has been paid to the behavioral and institutional microfoundations of change. Fundamental issues concerning cooperation, as well as the mechanisms facilitating or hampering such actions, can play a much more central role in attempts to unravel and address Amazon deforestation. We thus present the issue of preventing the Amazon biome from crossing a biophysical tipping point as a large-scale collective action problem. Drawing from collective action theory, we apply a novel analytical framework on Amazon conservation, identifying six variables that synthesize relevant collective action stressors and facilitators: information, accountability, harmony of interests, horizontal trust, knowledge about consequences, and sense of responsibility. Drawing upon literature and data, we assess Amazon deforestation and conservation through our heuristic lens, showing that while growing transparency has made information availability a collective action facilitator, lack of accountability, distrust among actors, and little sense of responsibility for halting deforestation remain key stressors. We finalize by discussing interventions that can help break the gridlock.
\end{abstract}

\section{Introduction}

The renewed rise in deforestation of the Amazon, along with its 2019 and 2020 forest fires, again brought global attention to the peril of its disappearance-the steady loss of the largest remaining tropical forest on the planet. The destruction of the Amazon is a concern not only because of the direct impact this has on carbon emissions and biodiversity loss, but also because of the role of the forest as a tipping element in the Earth system. The Amazon is likely to have a biophysical tipping point, a threshold beyond which a combination of direct human pressures-fires and deforestation, coupled with indirect pressures through climate change-could flip the system from a biodiverse moist, tropical rainforest to a less diverse dry, open forest or savanna (Lovejoy and Nobre, 2018; Wuyts et al., 2017; Lenton et al., 2008; Lenton et al., 2019). With climate change worsening and deforestation in the Amazon approaching a fifth of the total forest area, there are worrying signs that

\footnotetext{
* Corresponding author at: Stockholm Environment Institute, Box 24218, 10451 Stockholm, Sweden.

E-mail address: mairon.bastoslima@sei.org (M.G. Bastos Lima).
} 
such a tipping point might be imminent (Lovejoy and Nobre, 2019), with studies showing recent reductions in precipitation (Barkhordarian et al., 2019; Leite-Filho et al., 2020) and changes to forest composition (Esquivel-Muelbert et al., 2019).

Crossing the Amazon biophysical tipping point would have devastating effects both locally and globally. Spanning 5.5 million $\mathrm{km}^{2}$ in nine countries, the biome contains half of the planet's remaining tropical forests, hosts more than $10 \%$ of the world's remaining biodiversity, and is home to over 30 million people (of which about 1 million are indigenous people) (Nobre et al., 2016; Piotrowski, 2019). Conversion of the rainforest to a dry ecosystem could also release up to 90 billion metric tons of carbon dioxide to the atmosphere by 2100 (Steffen et al., 2018), constituting more than a fifth of the remaining carbon budget from 2021 onward if we are to limit warming to $1.5^{\circ} \mathrm{C}$ (with $67 \%$ certainty; IPCC, 2018). It would have direct impacts on global atmospheric circulation patterns, potentially intensifying warming across Central and East Asia, including the large agricultural area of northeast China (Snyder, 2010; Werth and Avissar, 2004).

It is not for want of attention that the Amazon is degrading. Since the mid-1980s, its fate has attracted much public and scholarly attention (Moran, 1993). There is a large body of literature on the underlying drivers of deforestation, including more recent studies on the role of international trade (Pendrill et al., 2019) and the effectiveness of different policy approaches (Boucher et al., 2013; Nepstad et al., 2014; Bastos Lima et al., 2017). These studies find complex interlinkages between natural and social processes, leading observers to describe environmental problems such as Amazon deforestation as "wicked" in the sense that they are inherently difficult to define and potentially unsolvable (DeFries and Nagendra, 2017; Balint et al., 2011; Mercure et al., 2019).

However, while research on complex social-ecological systems, such as the Amazon, has devoted much effort to describing complexity in terms of nonlinearity, connectivity, and limited predictability (Berkes et al., 2003), little attention has been paid to the behavioral and institutional microfoundations of change. That is, while research on Earth system governance or resilience focuses on important concepts, such as cascading effects, directionality, emergence, scale effects, and teleconnections (Biermann, 2012; Scheffer, 2009; Galaz et al., 2012), this article argues that fundamental issues concerning cooperation and coordination, as well as the mechanisms facilitating or hampering such actions, should play a more central role in any attempt to develop our understanding of complex systems such as the Amazon.

This article, therefore, utilizes an innovative collective-action lens to examine the issue of persistent Amazon deforestation. We argue that preventing the Amazon biome from crossing a biophysical tipping point can be understood as a large-scale collective action problem, and elaborate on a novel analytical framework for understanding the challenges of large-scale collective action (Jagers et al., 2020). This analysis can provide insights into the lack of concerted action to halt forest loss in the region, as well as help identify actions by different actors that can facilitate collective action to provide lasting support for Amazon conservation.

First, we review collective action theory, elaborate on stressors and facilitators of large-scale collective action, and refine these elements into variables that can be used to assess the conditions for collective action. Secondly, we apply these variables to the problem of Amazon deforestation, drawing on the extensive literature in (inter alia) land-use science, forest conservation and environmental governance. We examine underlying and proximate drivers of deforestation in the Amazon as well as governance responses at local to global scales, throughout recent history. We also build on recent data from platforms monitoring Amazon forest loss and its drivers (e.g., MapBiomas, Trase). Thirdly, we discuss what kinds of interventions could help move the identified variables toward facilitation and, thus, potentially lead to successful collective action. This includes identifying actors that could potentially intervene as third parties, laying ground for further research that may explore their individual ability or readiness to do so. We conclude the paper by showing how breaking down the problem of Amazon deforestation into smaller subproblems may foster more concerted targeted actions and, ultimately, help avoid its biophysical tipping point.

\section{Background: introducing a large-scale collective action framework}

A collective action problem refers to a situation in which actors are motivated to take a course of action that is more beneficial than costly to them individually but is more costly than beneficial to society, and in many cases to themselves over time. This generates a substantial risk that collective benefits will not be produced. Such a situation is often referred to as social dilemmas (Dawes, 1980). However, not all collective action problems, especially not all larger-scale collective action problems, are proper social dilemmas. Other coordination problems should be included as well (Jagers et al., 2020), including choices that do not necessarily affect the individual actor but other parties such as patients, children, clients, or future generations. Or situations where a principal, representing a group of actors, must come to an agreement with other such principals, as well as "race-to-the-bottom" situations, where even a small number of defecting actors can start a negative feedback loop, making cooperation less likely. Still, all types of collective action problems share a feature of proper social dilemmas in that they cannot be overcome, or managed, unless at least some actors act against their own short-term self-interest, or against the short-term interest of their principals. Such social dilemma (Dawes, 1980) and coordination (Jagers et al., 2020) models provide powerful ways to explain the origin of environmental problems and discussing how they can be overcome (cf. Hardin, 2009).

\subsection{Collective action facilitators}

The general literature on collective action has identified a number of factors that tend to facilitate cooperative behavior, which we refer to as facilitators. Examples of such facilitators include (1) possibilities for actors to punish free riders (Fehr and Gächter, 2000; Gächter and Herrmann, 2009); (2) transparency about others' behavior, such as decreased anonymity (Laury et al., 1995), as well as public disclosure and communication (Gächter and Fehr, 1999); and (3) small group size (Agrawal and Goyal, 2001; Carpenter, 2007; Isaac et al., 1994). In addition, Ostrom $(1990,1998,2010)$ found that the links among (4) trust, (5) reciprocity, and (6) good reputation are at the core of behavioral explanations of successful collective action. Other collective action facilitators are (7) prosocial preferences (Fehr and Gächhter, 2002; Fehr and Schmidt, 1999; Kerr, 1995), (8) prosocial norms and values (Biel and Thøgersen, 2007; Ostrom, 1998; Stern et al., 1999), (9) procedural and distributional fairness (Sutinen and Kuperan, 1999; Tyler, 2010; Wilke, 1991), and (10) equal power relations.

\subsection{Collective action stressors}

The literature has also identified factors that hamper collective action, which we refer to as stressors. Some of the most prominent stressors are: (1) Anonymity, which worsens as more actors are involved and is additionally reinforced as spatial and temporal distances increase (Greif, 1993; Ostrom, 1998). Likewise, (2) lack of knowledge about other actors' choices and actions has repeatedly been shown to decrease cooperative behavior (Rapoport et al., 1992). (3) Particularly with a growing number of actors and larger spatial and temporal distances, the possibility of observing individual actions tends to decrease, contributing to a lack of accountability (Adsera et al., 2003). (4) Heterogeneity, too, including differences in identities and socioeconomic status, as well as power asymmetries, jeopardizes the potential for establishing and sustaining reciprocal relationships, and hence also for building trust among actors (Baland and Platteau, 1996; Bardhan and Dayton-Johnson, 2000; 
Ostrom, 2010; Varughese and Ostrom, 2001). (5) Rivalry or conflict of interest hampers collective action and contributes to the tragedy of the commons (Hardin, 2009), while (6) Uncertainty and risk regarding consequences (e.g., lack of knowledge about the size of the shared resource) can also function as a stressor (Messick et al., 1983; Wit and Wilke, 1998).

\subsection{Large-scale collective action problems and the need for third-party interventions}

Most evidence on the prospects for successful collective action stems from relatively small-scale, small-N experiments (at best trying to mimic some larger-scale situation). Hence, while much can be learned from these studies, the circumstances are very different with respect to many of the challenges that humanity is facing today, including the rapid degradation of the Amazon. For example, while this literature has shown that small-scale and closely knit societies endogenously can develop rules and regulations - as well as ensure enforcement and monitoring of these rules and regulations (Ostrom, 1990; Agrawal and Goyal, 2001) - such solutions become less likely as the collective action problem becomes larger. Large-scale characteristics also increase the likelihood that the collective action problem is not a pure social dilemma, and that actors will have different incentives to engage in collective action.

A newly developed framework (Jagers et al., 2020) argues that a large-scale collective action problem is typically characterized by (1) a large number of actors, interacting over (2) large spatial and (3) temporal distances, and involving (4) high levels of complexity. These characteristics result in a situation where the spontaneous collective action among involved individual actors needed to overcome the problem is highly unlikely. As more actors get involved, the geographic distance between the involved parties grows, and there are temporal delays between actions, informal mechanisms tend to become far less effective. This accentuates the need for complementary mechanisms and institutions that can help actors overcome the cooperation and coordination problems they face (Jagers et al., 2020). In most cases, some kind of third-party intervention is needed to adjudicate disputes, enforce contracts, or facilitate communication. The most apparent third party is the government. In fact, coordination of actors and facilitation of collective action are core functions of the government (Mansbridge, 2014). This becomes challenging at the international level, where other actors such as multilateral, religious or business organizations, as well as environmental NGOs, often serve as third parties. These actors might become instrumental in situations where the relevant governments lack the political will or capacity to act as a constructive third party. Fig. 1 illustrates this dynamic. In order to reach a collective action tipping point (i.e., a situation in which successful collective action takes place), the stressors need to be weakened and the facilitators strengthened. (In many cases, these two objectives should be achieved simultaneously.)

As argued by Jagers et al. (2020, p. 1290), the larger the scale of the collective action problem, the more likely it is that third-party interventions will be needed to reach a collective action tipping point. There are two ways in which third-party interventions can help overcome large-scale collective action problems: (1) by coordinating through regulation (e.g., environmental taxes or cap-and-trade systems), thus avoiding or preventing the collective action problem in the first place, or (2) by promoting collective action among actors by affecting the variables presented above, reinforcing facilitators or weakening stressors, or both.

However, coordination through regulation requires a government that is both willing and able to put effective regulatory mechanisms in place. As long as there is no social or technical transformation to sustain the resulting behavioral change, it will be precarious in the sense of depending on continued regulatory and enforcement action on all relevant levels, including the international level if the problem is international in nature. This is perceptible in the Amazon case, where the impressive reductions in deforestation achieved through concerted policy action that started in 2004-through the Action Plan to Prevent and Control Deforestation in the Amazon (PPCDAm) (Nepstad et al., 2014; Arima et al., 2014)—have been eroded by the subsequent dismantling of such regulations and enforcement, notably under Bolsonaro (Abessa et al., 2019; Pereira and Viola, 2019). Given the current political situation in Brazil and the low probability of any multilateral regulation on Amazon conservation, we focus on the latter option: how third-party interventions can increase actors' propensity to cooperate.

Theoretically, third-party interventions are not a trivial issue, and there are several actor features that affect the likelihood of an actor being able to function as a third party. For example, while some have argued that facilitating collective action is "the core justification of the state" (Ostrom, 1998, p. 1) or "the most significant reason for government" (Mansbridge, 2014, p. 10), there is great variation in the extent to

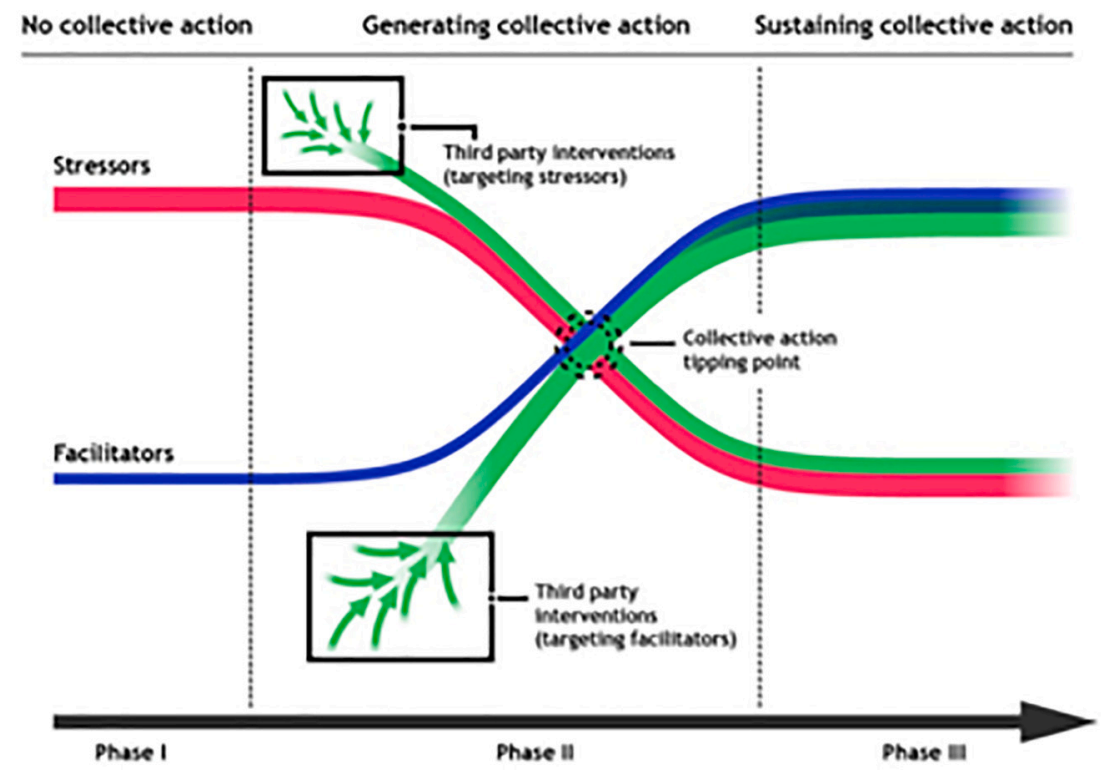

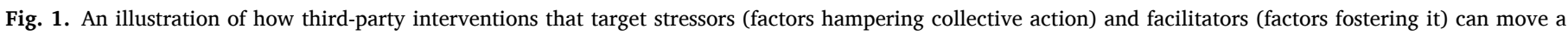
system to a collective action tipping point beyond which such an action emerges and can be sustained.

Source:Jagers et al. (2020). 
which states or other actors are actually capable of fulfilling this function. A third party needs, first and foremost, to have the power or ability to influence actors, to increase cooperation either by facilitation or through various forms of sanctions or enforcement tools. The prospect of being successful in its interventions is also determined by its perceived legitimacy, which in turn affects the likelihood of achieving compliance and being able to foster collective action (Levi, 2006; Arias, 2015).

\subsection{Stressors and facilitators as variables: a framework for analysis}

One can observe that stressors and facilitators often are two sides of the same coin, that is, they can often be regarded as variables. This is, for instance, evident for trust or distrust among actors, respectively regarded as a facilitator and a stressor of collective action. They can both be subsumed to a variable called horizontal trust (distinct from vertical trust, in institutions). Transparency and anonymity are both about information, which may be more or less available (or accessible). Similarly, the possibility to punish free-riders is as much a facilitator as lack of accountability is recognized as a stressor - therefore, accountability is a variable.

Fig. 2 shows how several of the collective-action stressors and facilitators identified in the literature can be construed as variables. Even if stressors and facilitators are not always specular images of one another, they still can be regarded as elements on opposite sides that either hamper or promote collective action, and which we interpret as often operating along continuums. For instance, our variable sense of responsibility ranges from feeling concern beyond the self to complete emotional disconnection from the collective-action problem. Here, prosocial norms, values and preferences, as well as procedural and distributional fairness, all constitute facilitators with the potential to generate concern, whereas the stressor emotional decoupling pulls that same variable in the opposite direction. While arguably there could be many more variables, we derive six as a framework to analyze the Amazon case.

\section{Amazon deforestation as a large-scale collective action problem}

The Amazon has experienced continuous-albeit fluctuating-deforestation in the last 50 years, bringing it steadily toward a biophysical tipping point. Uptake of atmospheric carbon dioxide by the rainforest already decreased by $30 \%$ from the 1990 s to the 2000 s, partly as a result of increased tree mortality (Brienen et al., 2015). Severe droughts in 2005 and 2010, triggering large-scale wildfires, led to the release of significant amounts of carbon and reduced the capacity of the remaining forest to absorb carbon from the atmosphere (Feldpausch et al., 2016). Most importantly, persistent logging and subsequent land use change for cattle ranching and cash-crop expansion have been rapidly clearing forest areas. Soy is an expanding crop in the region, often pushing cattle ranching further into the Amazon (Arima et al., 2011), and in some parts of the region oil palm, coffee, cacao and coca are also important drivers (Piotrowski, 2019). Finally, mining and hydropower development have opened land to other uses and thus indirectly contributed to deforestation (Sonter et al., 2017).

While most land use change and commodity-driven deforestation can be linked to domestic consumption in the Amazon countries (primarily of beef), forest loss is increasingly being driven by international demands, with Europe, the Middle East, and China as major consumers of what has been termed "embodied deforestation" (Pendrill et al., 2019; Henders et al., 2015; Zu Ermgassen et al., 2020a, 2020b). Similarly, fuzzy investment pathways-where money is often channeled through tax havens-support environmental degradation in the Amazon, resulting in further complexity (Galaz et al., 2018a, 2018b). Thus the drivers of deforestation-directly, through the agents of deforestation, and indirectly, through market demand, finance flows, and faltering institutions - encompass millions of people across the entire globe.
Avoiding an Amazon biophysical tipping point is a large-scale collective action problem that scores high on all four fundamental largescale characteristics: (1) a large number of actors, interacting over (2) large spatial and (3) temporal distances, and involving (4) high levels of complexity. Furthermore, these characteristics are reflected not only in the causes of Amazon deforestation but also in its consequences. Besides immediate socioeconomic impacts, in particular on traditional livelihoods of indigenous or other local communities, Amazon deforestation has many long-range and complex environmental impacts. The biome's destruction affects local and continental rainfall patterns, and because the Amazon is a tipping element in the Earth system, it would indirectly affect the entire global climate (Lovejoy and Nobre, 2018; Lenton et al., 2019).

This section therefore applies the large-scale collective action framework to understand the current status of the Amazon using the six variables identified: information, accountability, harmony of interests, horizontal trust, knowledge about consequences, and sense of responsibility. This examination provides an important overview of the Amazon conservation challenge that is then used (in Section 4) to identify potential third-party interventions that can promote collective action to reduce deforestation.

\subsection{Information}

Information on which actions affect the Amazon is a critical first step for any collective action governance effort, as poor predictability of how others will act has been identified as key for conditional cooperation in the provision of public goods (see, e.g., Keser and Van Winden, 2000). Lack of information stems partly from the sheer number of actors that contribute to Amazon deforestation, resulting in coordination problems across countries (either in the Amazon or consumer country governments), sectors (e.g., beef, soy, finance), and stakeholder groups (e.g., indigenous people, cattle ranchers). This coordination problem is exacerbated by its large-scale character, as it spans large spatial distances and exhibits great socioeconomic heterogeneity across involved actors. As shown in the literature on conditional cooperation, knowledge or expectations about others' contributions to a public good significantly affects one's behavior (Kocher et al., 2008).

Recently, a growing number of monitoring, transparency, and traceability initiatives have focused on identifying who does what, when and where as a way to reduce anonymity and attribute responsibility. These initiatives include (1) land use change monitoring, including realtime deforestation alerts (e.g., Brazil's DETER system), (2) registries and databases of who owns what in the Amazon, particularly farmland, and (3) traceability initiatives to shed light on financial and supply chains related to the Amazon, to identify who invests in land-based activities (Galaz et al., 2018a, 2018b) and who trades and consumes the commodities produced in the Amazon (Gardner et al., 2019). For instance, using cattle movement registries and customs data, the Trase platform ${ }^{1}$ indicates that about $80 \%$ of Brazil's beef production is consumed domestically, while China, Egypt, and Russia figure as its top three export markets, including which Amazonian municipalities supply which companies and whose markets (Zu Ermgassen et al., 2020a). Moreover, it has become possible to assess how individual actors-either consumer countries or private companies-that have committed to eliminate deforestation from their supply chains are performing (Zu Ermgassen et al., 2020b). Such detailed publicly available information databases have significantly increased transparency, thus helping create a baseline for action. Finally, a growing body of research has shed light on who causes what specific impacts on the Amazon, such as quantification of the greenhouse gas emissions implicated in particular commodity flows and their embodied deforestation (Escobar et al., 2020).

\footnotetext{
1 See http://trase.earth
} 
FACILITATORS

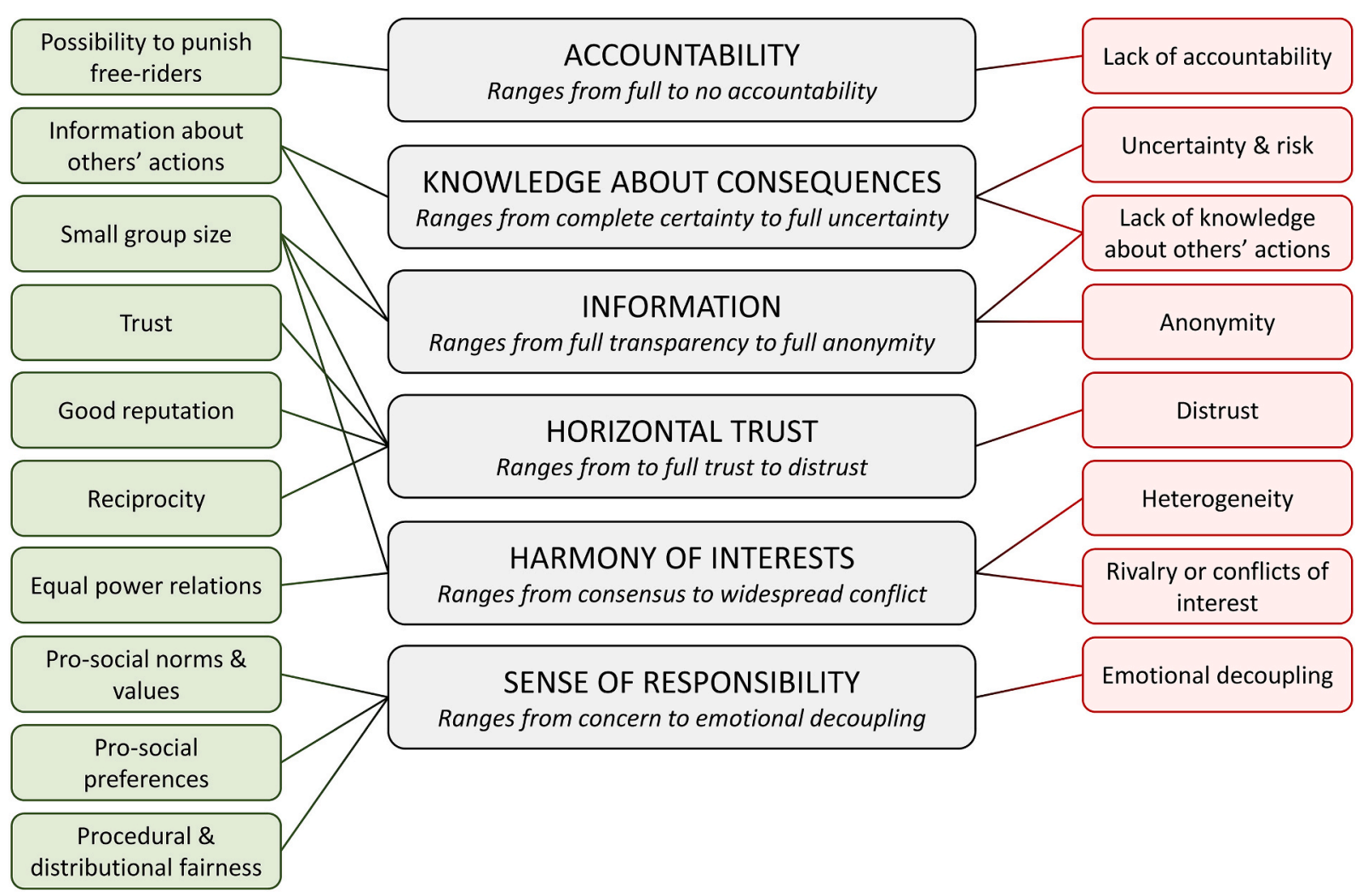

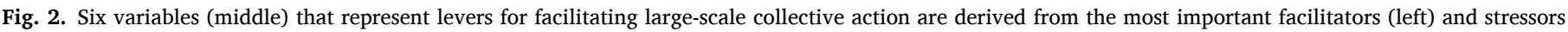
(right) that has been identified in the collective action literature. See text for details.

This collective action variable has therefore improved radically over the past 20 years, away from anonymity and toward growing transparency. Although more remains to be done in certain areas (e.g., tax havens, countries or jurisdictions that do not provide access to their data, fuzzy land ownership databases, false registries, and illegal products, such as timber or beef, often laundered as legal), a lack of information is no longer a hindrance for collective action in respect to reducing Amazon deforestation (Galaz et al., 2018b; Lambin et al., 2018; Gardner et al., 2019). Rather, information has increasingly become a facilitator of collective action and more sustainable land use.

\subsection{Accountability}

Despite the recent increase in transparency and understanding of who does what in the Amazon, accountability remains elusive. First, there is little consensus on norms of behavior, and therefore no agreement on which basis to assess who is accountable for what. For example, many companies-once publicly exposed as contributors to Amazon deforestation-have embraced zero-deforestation commitments, but there is no general agreement on what constitutes deforestation, whether legal deforestation should be tolerated, and whether to adopt zero gross or zero net deforestation, where the latter would allow for forest clearance to be compensated elsewhere (Garrett et al., 2019).

Second, there is no clarity as to who is accountable to whom. Principal-agent models of public accountability become fuzzy in the international sphere and when actions take place across legal and political borders (Mason, 2008; Gupta and Van Asselt, 2019). There is some degree of market accountability, where producers and traders may be accountable to their consumers for causing environmental impacts abroad, but this arguably falls short of what is needed (see Bäckstrand, 2008).

Third, there are no effective governance institutions in place that can decide on what constitutes norm-deviant behavior, enforce sanctions on transgressors, or regulate the redressing of damages. Some consumer countries have started to experiment with domestic regulations that have extraterritorial effects, most notably France's due diligence law to sanction companies that have assets in French territory and cause human rights or environmental violations abroad, but the effectiveness of these efforts has not yet been sufficiently assessed (Chen, 2018). The EU has been preparing regulatory action to reduce imports of embodied deforestation, yet the most politically feasible options so far are of voluntary nature (e.g., certification or multistakeholder forums) and fall short of full accountability (Bager et al., 2020).

While elusive at the international level, accountability is wavering within national borders in the Amazon. Brazil was particularly successful in reducing Amazon deforestation rates between 2005 and 2012 through a combination of policy restrictions, incentives, effective satellite monitoring, real-time deforestation alerts, and improved enforcement (Nepstad et al., 2014; Soares-Filho et al., 2014). However, these institutions were subsequently weakened, and law enforcement has reached new lows under Jair Bolsonaro's presidency (Abessa et al., 2019; Pereira and Viola, 2019). This is on top of persistent accountability problems, as research shows that less than $1 \%$ of the fines for environmental crimes in the Brazilian Amazon ever get paid (Börner et al., 2014).

An example of where accountability has been established is the Amazon Soy Moratorium. The agreement-signed by Brazil's two major industry associations of soy traders (comprising as much as $80 \%$ of Brazil's soy market) after significant pressure from international environmental NGOs and retailers-prohibits the sourcing of any soy produced on recently deforested land in the Amazon. Initially renewed every year, the moratorium was indefinitely extended in 2016. By creating an accountability system with clear rules, monitoring mechanisms, and sanctions- effectively excluding suppliers who have grown 
soy on areas deforested after 2008-the moratorium has significantly reduced direct conversion of Amazon forests to soy cropland (Gibbs et al., 2015). ${ }^{2}$

A key reason for its success has been that the collective moratorium has simplified coordination and reduced uncertainty about the behavior of other major players, effectively creating a level playing field. It has also established a multistakeholder forum for negotiations among relevant actors, the Soy Working Group (Bastos Lima and Persson, 2020). That said, similar attempts made regarding beef sustainability, with Brazilian cattle ranchers and meatpacking industries agreeing to act collectively toward improved practices, has yet to demonstrate results in terms of reduced deforestation (Gibbs et al., 2016; Buckley et al., 2019).

Overall, accountability remains a challenge for effective collective action in the Amazon. It has wavered over the years, diminishing in key regional countries such as Brazil while slightly improving at the international level as consumer countries such as France have put new laws in place. Some such initiatives facilitate collective action, but a lack of sufficient accountability for impacts still remains a significant stressor.

\subsection{Harmony of interests}

Major conflicts of interest underlie a lack of consensus over how the Amazon is to be governed as well as the absence of effective accountability mechanisms. While there is increasing global concern for the fate of the Earth's most emblematic ecosystem and growing public interest in developed countries in its conservation, these concerns are far from being consensual or harmonized with other interests. For one, there is a clash between forest preservation and the drive for local economic development. Moreover, South America has increasingly become a global breadbasket, expanding food production to meet the needs of a growing world population that increasingly embraces protein-rich diets, and this biases sustainability agendas in the region (Siegel and Bastos Lima, 2020). As transparency tools have now made clear, some of the same actors who call for Amazonian preservation are at the same time consumers of beef, leather, minerals, and poultry or pork fed with soy grown in the Amazon (Trase, 2018). This reveals that conflicts of interest-often unnoticed or at least unacknowledged-occur even within individual actors, be they persons or consumer countries that defend Amazon conservation while indirectly contributing to its demise.

A lack of harmonization between sustainability and development often underlies such conflicts of interest. Conservation policies frequently do not take sufficient account of local socioeconomic needs or aspirations in the Amazon. In Colombia's coffee belt, for example, even fully certified farmers often fail to make ends meet (Dietz et al., 2020). Overall, consumers' zero-deforestation commitments seldom involve considerations of social dimensions (Newton and Benzeev, 2018). Frequently pointing that out, agribusiness lobbies have generally opposed conservationists on the grounds of a right to development, while arguing that countries in the Global North and their organizations have no right to demand the large-scale forest conservation that they themselves have failed to accomplish at home. Growing evidence of the negative impacts of deforestation on the local climate and hence on crop yields (Oliveira et al., 2013; Cohn, 2017; Coe et al., 2017) may soften more radical opinions and help harmonize forest conservation interests with agricultural development interests. Yet, as rising rates of deforestation under Bolsonaro's presidency in Brazil make clear, uptake of those balanced views is limited when they require costly or significant changes to business as usual.

In sum, increasing evidence points to potential synergies between conservation interests and local development agricultural interests, or at least that they can be reconciled (Strassburg et al., 2014). However, in

\footnotetext{
${ }^{2}$ Issues of indirect land use change-where the expansion of soy on pastures are pushing cattle ranchers into the forest-remain to be addressed (see Arima et al., 2011).
}

practice, conflicts of interest remain a potent stressor hampering collective action in the Amazon.

\subsection{Horizontal trust}

Distrust among actors has been another key stressor at play. Perhaps the clearest example is the long-standing and widespread fear of internationalization of the Amazon, particularly prevalent in Brazilian deliberations (Arnauld de Sartre and Taravella, 2009). The idea that foreign forces aim to take control of the Amazon and its resources was repeatedly used by the Brazilian military dictatorship during the 1960s and 1970s as an argument for large-scale colonization of the region. Integrar para não entregar ("to integrate in order not to hand over") was for a long time a powerful motto behind Brazil's Amazon development policy. The same fear resurfaced in the 1980s and 1990s in the lead-up to the 1992 Rio Summit, with the argument that environmental concerns were only a pretext for the Global North to stop Brazil from developing, thus asserting national sovereignty and control over the Amazon (Kolk, 1998). More recently, such international distrust again became evident following the 2019 fires in the Brazilian Amazon. While there was a global public outcry spearheaded by French president Emmanuel Macron's statements that "the Amazon forest is a subject for the whole planet" and that Brazil could not be allowed to destroy it all (Associated Press, 2019), the Brazilian government rejected funds offered by the G7.

Where distrust among actors has been addressed, however, cooperation over the Amazon has occurred. An early example of this was the Pilot Program to Conserve the Brazilian Rainforest (PP-G7), which was established following the 1987 forest fires (Kolk, 1998) and, inter alia, paved the way for the demarcation of indigenous reserves in the Brazilian Amazon. Kolk (1998) argues that one reason for the success of the PP-G7 was the way it built trust by accounting for political sensitivities and involving local stakeholders in the process. More recently, REDD+ projects across the Amazon have also stressed the need for trust-building in realizing reduction of emissions from deforestation and forest degradation (Castro-Nuñez et al., 2017; Evans et al., 2014; Bastos Lima et al., 2017). Likewise, a key enabling factor for the Amazon Fund-which, since its inception in 2007, has channeled over US $\$ 1$ billion in conservation funding, primarily from Norway and Germany-was the degree of trust placed in the Brazilian institutions appointed to manage the fund, as well as the fact that this setup respected Brazilian sovereignty (Birdsall et al., 2014). This example also illustrates how quickly trust erodes and the detrimental impacts this can have on conservation: fund management changes announced by the Bolsonaro administration led first Germany, then Norway, to stop payments altogether, bringing new disbursements into the fund to a standstill.

Such international distrust affects not only the prospects for international cooperation on the Amazon but also domestic action, as the internationalization narrative is used by powerful agribusiness elites to question the motives of environmental NGOs and even of federal policy for forest conservation (Arnauld de Sartre and Taravella, 2009). This feeds into already very polarized and often conflictive local contexts, where the murder of activists and community leaders is rampant, human rights violations are commonplace, and long-standing opposition exists between social groups (Scheidel et al., 2020). In some cases, such as in post-conflict Colombia, government leadership has been able to increase trust and promote collective action (Furumo and Lambin, 2020). However, this remains the exception rather than the rule in the Amazon, where pervasive distrust continues to be one of the most powerful stressors hindering successful collective action.

\subsection{Knowledge about consequences}

Lack of knowledge about the consequences of (in)action can also be an important barrier to collective action (Barrett and Dannenberg, 2014). This stressor needs to be understood both in terms of the availability of knowledge and its accessability and uptake among relevant 
actors. An increasingly robust natural science basis shows that the Amazon's biophysical tipping point is strongly linked to the amount of deforestation in combination with climate change. When a threshold is crossed-currently understood as somewhere between 20 and $25 \%$ of the original forest being lost, under climate change scenarios meeting the Paris climate target- the Amazon would enter a biophysical dieback process of conversion, via drought and wildfires, into a drier ecosystem (Lovejoy and Nobre, 2018; Wuyts et al., 2017). Because of the rainforest's role in recirculating and transporting moisture across South America, that process would (also) impact millions of people in southern Brazil, Uruguay, Paraguay, and central-eastern Argentina, where winter rainfall would be negatively affected (Lovejoy and Nobre, 2018). Beyond that, some studies suggest that places as distant from the Amazon as China could experience detrimental impacts in the form of a drier climate (Snyder, 2010).

Still, despite growing scientific evidence on the ecological consequences of an Amazon forest dieback and its global teleconnections, access to such knowledge remains minimal. There is little popular understanding of this environmental issue in spite of its magnitude even within Amazonian countries, let alone in other parts of the world implicated in this collective action problem (e.g., commodity consumers or countries that would be significantly affected by an Amazon forest dieback). For instance, in August 2019, the Brazilian public experienced a sobering, heightened sense of concern when scientists confirmed that unusually dark skies in São Paulo - thousands of kilometers away - were partly caused by Amazon fires (Setzer, 2019). However, events such as these remain the exception rather than the rule in public perception. Media representation of Amazon deforestation, both in Brazil and in Europe, remains limited and generally fails to convey the complexity of the issue or its underlying causes (Ladle et al., 2010). In addition, powerful agribusiness lobbies without an interest in the controversy about Amazon deforestation often set the media's agenda and navigate public perceptions away from those issues (Lahsen, 2017).

Scientific knowledge is increasing about the consequences of Amazon deforestation and who will likely be most affected. Yet, this knowledge remains exceedingly technical and mostly limited to experts. Most stakeholders fail to comprehend it. Therefore, it is not so much the availability of but the access to knowledge about consequences that seems gravely missing and remains a key stressor hampering further collective action.

\subsection{Sense of responsibility}

Sense of responsibility, ranging from a feeling of concern to total emotional detachment (McDonald et al., 2015; Trope and Liberman, 2010) is an often-overlooked variable when it comes to Amazon conservation. Several of the mechanisms that tend to erode actors' sense of responsibility, both in the forward-looking (for successful collective action) and in the backward-looking sense (for the problem), are clearly present in this case.

Until the mid-twentieth century, the Amazon had been largely viewed as little more than a "torpid backwater" and "a place whose prominence seemed well in the past" (Hecht, 2011, p. 203). However, this view gradually changed as the Amazon became a development frontier and as environmentalism gained ground in many parts of the world. The Amazon would grow to prominence as the Earth's most emblematic terrestrial biome, yet this has not meant widespread global concern for its conservation beyond some more affluent Western countries. Globally, key consumer regions of commodities produced at the cost of Amazon deforestation (e.g., leather in Italy, beef in China or the Middle East) remain rather aloof and unresponsive (see, e.g., Mammadova et al., 2020), while locally, land use has been primarily guided by Euro-American modernist ambitions (Hecht, 2011) that only recently encountered significant political opposition from alternative views, such as Sumak Kawsay and buen vivir. These indigenous or indigenous-based alternative framings embrace Amazon conservation at heart, questioning Western notions of development (Coq-Huelva et al., 2018). However, while present in key Amazonian countries such as Ecuador and Bolivia, such alternative views remain peripheral in comparison with the dominant views that either disregard Amazon deforestation or see it as a necessary cost of progress.

The human costs of Amazon deforestation-mostly overlooked as nameless and faceless locals-have also remained obscure. It is telling that what has both directed the international spotlight at the destruction of the Amazon and raised the issue on the domestic agenda has been particular events, such as the murders of rubber tapper Chico Mendes in December 1988 and Sister Dorothy Stang in February 2005. By attaching "an identifiable human face to a cause that had previously been advanced primarily by scientists and foreign environmentalists" (London and Kelly, 2007, p. 43), the death of Chico Mendes helped pave the way for the establishment of an extensive natural park and forest reserve network in the Brazilian Amazon, as well as the end of fiscal programs incentivizing Amazon deforestation. Similarly, the murder of Dorothy Stang, a 73-year-old American Catholic nun who helped organize smallholder cooperatives against land grabbing by ranchers, led to a global outcry and the demarcation of an additional 8.2 million hectares of forest reserves (ibid.). But as noted by London and Kelly (2007, p. 220), "Once the perpetrators had been apprehended, the story left the headlines, and life returned to normal in the Amazon."

In sum, there is overall a growing sense of responsibility for the fate of the Amazon but this is far more visible in social groups where environmentalism is more strongly present than elsewhere. Most stakeholders in this large-scale collective action problem arguably remain emotionally disconnected from the deforestation issue, even if not always entirely unaware of it. Moreover, as commodity supply chains from the Amazon reach ever wider, how to connect and create a sense of responsibility in different societies and cultural contexts as distinct as southern Brazil, Europe, China, and the Middle East remains a crucial challenge for collective action.

\subsection{Summing up the Amazon challenge in terms of collective-action variables}

Based on current knowledge about the Amazon, Fig. 3 summarizes the analysis above, graphically illustrating the current status of each variable. We can see that while the large-scale characteristics of the Amazon certainly give rise to a number of severe stressors, some variables are rather working as facilitators of collective action. Accountability, harmony of interests, and horizontal trust seem to be the variables most heavily tilted toward the stressorside rather than the facilitatorside at present. Conversely, since many efforts to increase transparency have been successful, the variable information is leaning much more toward the a facilitator side than the stressor side. Disentangling these stressors and facilitators in this manner may indicate potential levers and key areas of intervention for third parties.

\section{Third-party interventions in the Amazon case}

A number of third-party interventions could potentially change the Amazon's prospects. There are several initiatives that actors with some measure of power and legitimacy can take that would affect the current standing of one or more of those six collective action variables, either by mitigating their roles as stressors (e.g., conflict of interests) or by enhancing facilitators (e.g., accountability). Those actors could include Amazonian or consumer-country governments, international organizations (including the UN), business organizations, NGOs, faith-based organizations, the scientific community, and the media. It is impossible to anticipate exactly how much any of these actors would need to "move" the variables in order to reach a collective action tipping point, but the directionality is clear. That is, improvements in transparency, accountability, harmony of interests, horizontal trust, knowledge about consequences, and sense of responsibility would arguably all improve the 
Facilitator Stressor

Information (about actors and their actions)

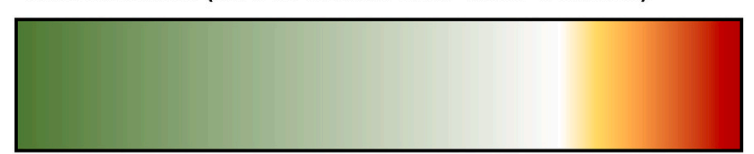

Accountability

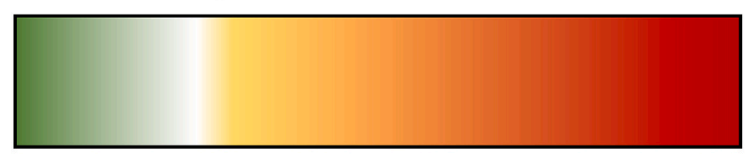

Increased accountability for supply-chain \& finance actors, by consumer country governments.

Harmony of interests

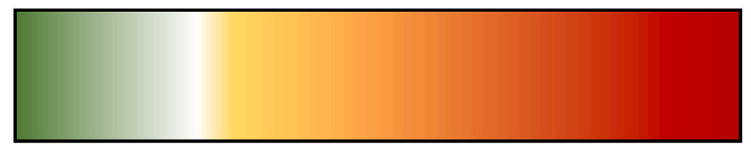

Aligning economic incentives for conservation, by donors; support for alternative business models, by governments \& finance institutions. organizations \& governments; translation \&

dissemination of available data, by NGOs \& media.
Initiatives for increased transparency, by business
Horizontal trust

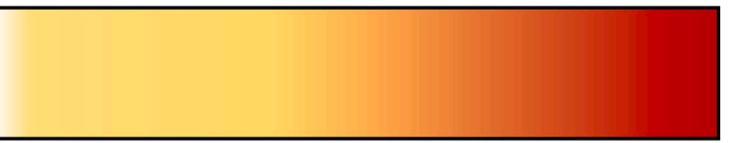

Knowledge about consequences

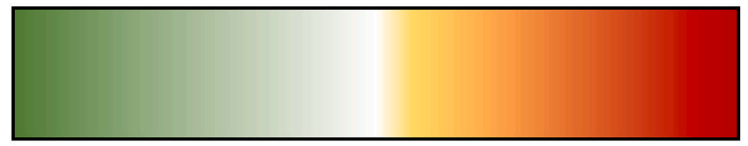

Dissemination of existing knowledge, by knowledge

institutions, media and CSOs.
Local \& multi-lateral trust-building activities, by multilateral institutions and through multi-stakeholder dialogues.

Sense of responsibility

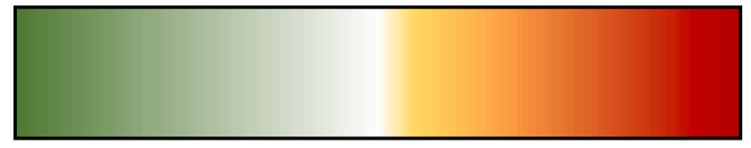

Faith-based organizations, the media, and NGOs can emphasize sense of responsibility (rather than guilt) and conservation synergies (rather than conflicts)

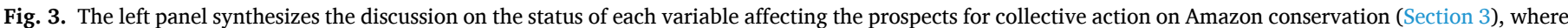

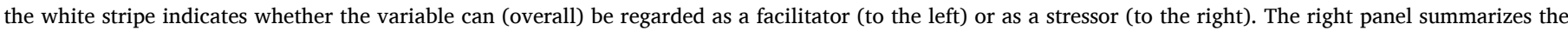

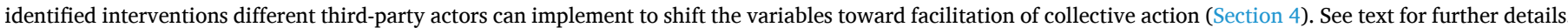

prospects for successful collective action. The remainder of this section discusses a number of potential third-party interventions that might affect each of the six variables, as well as the actors that could play such roles in each specific case.

\subsection{Interventions to improve information}

For the Amazon, as for other tropical ecosystems, greater transparency has been key in advancing a sustainable land use agenda (Gardner et al., 2019). National and subnational governments in the region, along with the scientific community, have played key roles in producing and publishing data that allow assessments of land use patterns, deforestation drivers (e.g., consumers, financiers), and how different actors are involved in the complex web of relationships that currently result in Amazon destruction. Still, despite much progress in increasing transparency, supplier anonymity-and thus deforestation risk-remains an issue in some crucial commodity chains such as beef, where indirect suppliers are prevalent. Besides traceability challenges, commodity traders often are reluctant to publish information that could potentially benefit their competitors. Therefore, business organizations such as the Consumer Goods Forum and the Soft Commodities Forum-both of which involve CEOs of major agricultural commodity traders-have a key role to play in facilitating coordination and in leveling the playing field. Consumer country governments, too, could intervene to that end. These third parties could request, for instance, that a critical mass of commodity traders that source from the Amazon be equally transparent about their sourcing. Meanwhile, more governments in the region could-with adequate financial and technological support-emulate Brazil in producing real-time deforestation alerts.

Yet information should not just be available in principle but also easily accessible in practice. The fact that such data are released does not mean stakeholders are well informed or even understand that information. Environmental NGOs as well as the media can enhance transparency as a collective action facilitator by further translating and disseminating scientific information about the Amazon. A betterinformed public is better equipped to exert pressure on decisionmakers both as citizens and as consumers. Moreover, NGOs and the private sector, in concerted multistakeholder efforts, can strengthen meta-certification initiatives and reduce consumer confusion in the face of an overload of sustainability labels and certificates for goods from the Amazon (see Dendler, 2014; Janssen and Langen, 2017).

Finally, third-party interventions are urgently needed to scrutinize critical information on the legality and origin of products such as timber and beef, information that is often tampered with (Bisschop, 2012). Because of inadequate law enforcement, corrupt officials-in collusion with loggers and international traders-far too often "legalize" illegal timber and thus provide false information to many consumers (Bisschop, 2012). Likewise, the practice of "cattle laundering" may also require 
more adequate tracing of indirect suppliers by meatpacking industries that can provide reliable information (Alix-Garcia and Gibbs, 2017; Buckley et al., 2019). Critically, even new tools such as blockchain technology depend on having accurate and trustworthy information inputs at the source (Saberi et al., 2019). The financial sector and consumer actors could both enhance capacities on the ground and set firm demands in partnership with national and subnational Amazonian governments to more adequately scrutinize and enforce public and private regulations on these issues.

\subsection{Interventions to improve accountability}

Third-party interventions to improve accountability may come in different forms and take place at different levels. Most fundamental is that Amazonian governments be both willing and able to strengthen law enforcement and domestic accountability systems against deforestation. As much as $99 \%$ of Amazonian deforestation in Brazil is illegal, and yet it goes mostly unpunished (MapBiomas, 2020). When public institutions detect and punish actors that violate the law, free-ride, or break contracts, this has important behavioral implications at the individual level. That is, effective punishment can function as deterrence (Rothstein and Stolle, 2008; Rothstein and Eek, 2009). Such interventions would thus have a direct effect on the prospects for successful collective action.

Accountability was successfully improved in Brazil from 2005 to 2012, when Amazon land use monitoring was ramped up and laws were rigorously enforced, resulting in an impressive reduction of $80 \%$ in deforestation rates. That experience clearly showed the critical importance of accountability systems that often are already in place but not sufficiently enforced. While these systems were significantly weakened by later governments, notably the Bolsonaro administration since 2019 (Artaxo, 2019), they can be strengthened again if Brazil and other Amazonian governments are persuaded to act.

Meanwhile, consumer-country governments and industry boards in the food and feed industries have key roles to play in promoting greater accountability for long-distance environmental impacts caused in the Amazon. This requires clear rules as well as sanctions and redress mechanisms to regulate the sourcing of agricultural commodities. France's due diligence law applying to all private companies with either headquarters or assets in French territory is possibly a way forward (Cossart et al., 2017). Such mandatory due diligence, now being emulated in other countries such as Germany and the UK, can level the playing field and improve accountability by allowing civil society to bring companies to court also in the consumer country if needed. The current discussions on adopting EU-wide due diligence legislation that also includes explicit provisions on deforestation-risk proofing is a promising option for scaling this up, and it could also be replicated elsewhere (Bager et al., 2020).

\subsection{Interventions to harmonize interests}

The harmonization between socioeconomic interests and Amazon conservation concerns can be successfully addressed if producer or consumer countries reorient their policies toward sustainable agri-food systems, breaking the perceived dichotomy between food production or economic development and forest conservation. The Amazon offers plenty of examples of how the two can go hand-in-hand.

There is ample evidence that agricultural development and forest protection can be reconciled, e.g., through sustainable intensification in crop production and cattle ranching (Cohn et al., 2014; Stabile et al., 2020; Strassburg et al., 2014). While supply chain actors in major businesses may fail to voluntarily initiate changes toward sustainable intensification, local authorities, financiers, and consumer countries are in a position to do so by providing agricultural extension services (Stabile et al., 2020), offering (conditional) rural credit or payments for ecosystem services (PES) (Cortner et al., 2019), or increasing demand for sustainably produced commodities (Bager et al., 2020). Aligning incentives plays a key role in inducing such large agricultural sectors at the forest frontiers to become more sustainable. Assunção et al. (2020) show, for example, how modifying rural credit to create stricter requirements regarding forest clearing markedly helped reduce deforestation in Brazil. At the international level, while World Trade Organization rules prevent consumer countries from discriminating against commodities on the basis of how they are produced, such countries can still reorient their international aid and consumption patterns to foster sustainable land use alternatives for the Amazon (e.g., value-chain development for moving local people away from economic activities that drive deforestation).

There is critical room for financial incentives, consumer demand, and development assistance to help foster local economic development alternatives. Value chains based on native goods (e.g., Brazil nuts, açaí berries, and numerous novel bioeconomy chains for the cosmetic and pharmaceutical industries) can be part of agroforestry systems and offer key sustainable development options that keep the Amazon rainforest standing (Nobre et al., 2016).

\subsection{Interventions to improve horizontal trust}

Distrust has been one of the most challenging stressors preventing successful collective action to protect the Amazon. Initiatives aimed at increasing horizontal trust among actors often critically depend on vertical trust in the third party providing the trust-building initiatives. Some researchers argue that perceptions in the vertical dimension have a causal effect on horizontal trust, since expectations regarding the third party have spillover effects on the expectations regarding other actors (Rothstein, 2005). For example, a third party that fulfills its function in a fair, uncorrupt and efficient way sends a signal to other actors about the general moral standard of the society in which they live (Rothstein and Stolle, 2008; Rothstein and Eek, 2009; Levi, 1998). The quality of "order institutions"- - that is, the police and other legal institutions, such as PPCDAm in Brazil-is often claimed to be of particular importance, since their purpose is to detect and punish people who free-ride or break contracts (Rothstein and Eek, 2009; Rothstein and Stolle, 2008).

In the Amazon case, major distrust exists among stakeholders (e.g., between commodity traders and environmental NGOs), as well as between producer and consumer countries. With regard to the former, the Soy Working Group-involving NGOs and soy traders who collectively manage the Amazon Soy Moratorium - has effectively shown that such multistakeholder platforms can help overcome distrust. Although it critically depends on willingness from the private sector to voluntarily compromise on business as usual, and even though the governance agenda risks becoming too narrowly defined by commodity export interests in what some call "commodity-centric landscape governance," engaging key players and sectors shows promise (Bastos Lima and Persson, 2020).

With regard to distrust among nations, such as between Brazil and European countries, third-party interventions need international arrangements that have both power and legitimacy in the eyes of all parties. Such an intervention could come either from UN agencies or from small groupings of both Amazonian and key consumer countries to express requests, discuss concerns, and potentially reach a compromise-elevating mutual trust in the process. Until its suspension in 2019, the Amazon Fund represented such an instance, where the participation of civil society as brokers and mediators helped bridge donor and recipient country interests to coalesce around conservation (Forstater et al., 2013). Trust-building initiatives could also be undertaken at the regional level through arenas for communication and exchange of experiences, which is important given that actors in Amazon differ greatly in terms of resources and power (Uslaner and Brown, 2005). 


\subsection{Interventions to improve knowledge of consequences}

Scientists and government agencies, along with international organizations such as the Intergovernmental Panel on Climate Change, have continually provided information on the consequences of further Amazon deforestation. Such knowledge exists, but too many actors directly involved in Amazon land use governance-not to mention the broader public - remain unaware of it. Third-party interventions are particularly critical for diffusing such knowledge both locally and globally. The entertainment industry as well as the media and different religious organizations can play important roles in spreading that knowledge, particularly among audiences that can politically affect key decision-makers. These audiences include local farmers and cattle ranchers, but also food consumers and those in civil society who can advocate for better accountability systems, a harmonization of ecological and socioeconomic concerns, and so forth. One limitation is that media organizations in key countries such as Brazil or Colombia are often funded by agribusiness and are therefore reluctant to disseminate knowledge that could be perceived as critical. For example, Lahsen (2017) exposes how the Brazilian media systematically prevents environmental critiques of Brazil's cattle ranching from reaching the broader public. Given the pivotal role of that sector for Amazon deforestation and the fact that $80 \%$ of Brazil's beef production is domestically consumed, these consumers are too important to be neglected, but they may need targeting by other media entities who can diffuse such knowledge. The lesson is that third-party interventions may require some repositioning of willing actors, beyond preaching to the converted.

It is important that the very actors that currently contribute most to Amazon deforestation understand that they themselves will be negatively affected if the Amazon crosses its biophysical tipping point. Not only would environmental impacts compromise agricultural production in the Amazon, disrupting food supply chains worldwide, but climatic impacts at the level of the Earth system as a whole could affect regions as remote as northern China due to the complex nature of the global climate system. Therefore, civil society organizations as well as scientists could try to communicate more effectively about such long-distance impacts to those key actors, such as Chinese consumers. This, in turn, could create concern-self-interested or not-to help promote collective action.

That being said, it is important to note that different kinds of knowledge are a necessary but not a sufficient condition for action. We can see this in the classic tragedy of the commons, where actors are aware of environmental deterioration but remain unlikely to change their behavior because it is not in their short-term self-interest to do so. In small-scale settings, actors can sometimes handle the problem by communication or exchange of information (Ostrom, 1990; Ostrom et al., 1992). In large-scale settings, however, knowledge and concern are not always sufficient for action or behavioral change. There is an extensive literature showing that knowledge about environmental deterioration does not automatically lead to action (e.g., Kollmuss and Agyeman, 2002), where the inaction is not just due to lack of information about the status of the resource, but also about "(a) which specific actions to take, (b) how to undertake actions of which one is aware, and (c) the relative beneficial impacts of different actions" (Gifford, $2011 \mathrm{p}$. 291). Hence, in the Amazon case, knowledge about what each individual actor can do must be better disseminated. It is important for actors to know not only how the biophysical tipping point works but also how to effectively act on that information (Fischer et al., 2019).

\subsection{Interventions to improve actors' sense of responsibility}

Third-party interventions are also needed to bridge the emotional disconnection between most people and the cumulative impacts of their individual actions on the Amazon. Various authors have explored the role of social norms in influencing individual behavior with respect to the environment (e.g., Jamieson, 2017; DeSombre, 2018). Feeling responsible (or even accountable) becomes particularly challenging in the face of long spatial and temporal distances. Much depends on improving ecological literacy (Orr, 1990), as well as on fostering greater biophilia-"an emotional affiliation of human beings to other living organisms" - and a conservation ethic (Wilson, 2017, p. 249).

Influential social actors such as faith-based organizations and the media already play key roles in orienting public attention, and they may also play key roles in creating a keener sense of concern by promoting feelings of connectedness and responsibility. The need to better integrate religions into the environmental movement has long been recognized (e.g., Boyd, 1984), yet religion remains a critical gap both in environmental social research and in advocacy with respect to deforestation. People who feel personal responsibility are more likely to take climate action, for instance (Bouman et al., 2020). However, such campaigns or messages must take people's reactions into account. For example, focusing on personal responsibility might generate feelings of guilt and cognitive dissonance, which in turn might lead to inaction. A sense of collective responsibility, for instance, can reduce feelings of personal guilt (Obradovich and Guenther, 2016). Business responsibility, in contrast, is more likely to be facilitated by regulatory threats and shareholder action (Reid and Toffel, 2009).

Finally, within multistakeholder and scientific debates on food versus forests, there is a need to move beyond a "production-at-all-cost narrative" (Bahar et al., 2020), which some refer to as based on a neoMalthusian discourse that emphasizes global population growth and makes this concern trump all else while neglecting other crucial aspects of food security, such as economic access to food, nutritional diversity, or food cultures (De Schutter, 2017). Stakeholders may find greater willingness and resolve to connect to the Amazon and engage more meaningfully in substantive action to keep the forest standing if its felling is not justified in terms of feeding the hungry and if sustainable agriculture alternatives are made more prominent.

\section{Conclusions}

The deforestation of the Amazon has typically been described as a highly complex problem, characterized by properties such as nonlinearity, connectivity, and limited predictability. Consequently, it has been analyzed by using concepts like cascading effects, directionality, emergence, scale effects, and teleconnections, all of which may be valuable to understand the problem but be of limited use for guiding concrete action and providing policy advice.

In this article, we have instead addressed this comprehensive challenge by arguing that fundamental issues concerning cooperation and coordination should play a more central role in any attempt to develop our understanding of the problems associated with the deforestation of the Amazon as well as to overcome these (sub)problems.

We do this by recognizing that Amazon deforestation constitutes a large-scale collective action problem where a voluntary and spontaneous solution among involved individual actors is highly unlikely. Therefore, third-party interventions are needed to realize the muchcalled-for collective action. Several types of such third parties might be relevant in this context, including business, religious or intergovernmental organizations, as well as social and environmental NGOs.

This alternative approach enables us to break down the overall problem into a set of variables (constituted by lack of facilitators or presence of stressors) currently hindering any successful overcoming of deforestation. These variables are information, accountability, harmony of interests, horizontal trust, knowledge about consequences, and a sense of responsibility. Taking these variables as a point of departure, we suggest a number of potential interventions that can either mitigate cooperation stressors or enhance facilitators.

There are several important findings. First, by deviating from the general pattern of mainly viewing and treating the Amazon as one comprehensive problem and instead breaking it down into smaller subproblems, it is possible to find new avenues for governance and 
policy advice. Second, this makes it possible to identify important core variables that any future governance of the Amazon need to influence. Although no exact order of prioritisation is established, the analysis indicates which variables currently are in a more critical state and may thus be more important to target at the moment.

Third, we identify two potential forms of third-party intervention that can be used to address the large-scale collective action problem of protecting the Amazon. A third-party actor, normally the state, can alter the character of the problem directly by imposing certain policies or sanctioning certain actions. However, this requires (Amazonian) states to be both willing and able to implement and maintain sufficient regulatory policies over time. The other form of intervention is to address the problem indirectly by promoting facilitators and weakening stressors. As has been noted above, this can be done by a variety of potential third parties at different levels. These two approaches do not conflict but are rather complementary: many of the regulatory measures traditionally proposed for reducing Amazon deforestation-such as land tenure regularization, enforcement of existing forest legislation, PES, credit and technical assistance for sustainable intensification - can also help support collective action by establishing accountability, harmonizing interests, and changing social norms.

Finally, our results clearly imply that there is no panacea for the Amazon deforestation problem, nor is there only one third party that can invent and implement the governance structures and interventions that are called for. Still, the present analysis can help potential third parties understand their role in relation to manageable subproblems of the overall Amazon deforestation challenge. It can also help identify important third parties in relation to specific key variables. In order to provide more precise and targeted advice on where and how to intervene, or how to allocate limited resources wisely, we need future research on the relative significance of different variables and their interrelations. To further strengthen this framework, we also need to know more about what characteristics of individual potential third parties can make constructive interventions more likely. This is most probably determined by many factors, including their respective power and impact, and to what extent they are trusted and perceived as legitimate among those who will be affected by their interventions. In this way, numerous third parties can each contribute to the solution of this largescale collective action problem, which is of such importance to all of us.

\section{Contributions}

MBL, NH, SCJ, ÅL, MP and MS contributed to all sections of the paper and are responsible for the majority of the writing. BB, DL, WS and FA contributed significantly to the writing of parts of the paper and/or contributed to the fundamental thinking and model.

\section{Funding}

We gratefully acknowledge funding from the University of Gothenburg to the Center for Collective Action Resesarch (CeCAR), grant 2312014-1181.

\section{Declaration of competing interest}

We hereby certify that none of us has any conflicts of interest related to the publication of this work.

\section{Acknowledgements}

The authors would like to thank Arun Agrawal, Andreas Nilsson, as well as two anonymous reviewers for ideas and comments that helped improve this article. This research contributes to the Science Plan of the Global Land Programme (GLP).

\section{References}

Abessa, D., Famá, A., Buruaem, L., 2019. The systematic dismantling of Brazilian environmental laws risks losses on all fronts. Nat. Ecol. Evol. 3, 510-511.

Adsera, A., Boix, C., Payne, M., 2003. Are you being served? Political accountability and quality of government. J. Law Econ. Org. 19 (2), 445-490.

Agrawal, A, Goyal, S, 2001. Group Size and Collective Action: Third-party Monitoring in Common-pool Resources. Comparative Political Studies 34 (1), 63-93. https://doi. org/10.1177/0010414001034001003.

Alix-Garcia, J., Gibbs, H.K., 2017. Forest conservation effects of Brazil's zero deforestation cattle agreements undermined by leakage. Glob. Environ. Chang. 47, 201-217.

Arias, A., 2015. Understanding and managing compliance in the nature conservation context. J. Environ. Manag. 153, 134-143.

Arima, E.Y., Richards, P., Walker, R., Caldas, M.M., 2011. Statistical confirmation of indirect land use change in the Brazilian Amazon. Environ. Res. Lett. 6 (2), 024010.

Arima, E.Y., Barreto, P., Araújo, E., Soares-Filho, B., 2014. Public policies can reduce tropical deforestation: lessons and challenges from Brazil. Land Use Policy 41, 465-473.

Arnauld de Sartre, X., Taravella, R., 2009. National sovereignty vs. sustainable development lessons from the narrative on the internationalization of the Brazilian Amazon. Polit. Geogr. 28, 406-415. https://doi.org/10.1016/j.polgeo.2009.09.008.

Artaxo, P., 2019. Working together for Amazonia. Science 363 (6425), 323.

Associated Press, 2019. The Latest: Macron Calls Amazon an Issue for Whole Planet, 27 August. https://www.apnews.com/9193fb6a2dc84d55bbc67b16d650b9bc.

Assunção, J., Gandour, L., Rocha, R., Rocha, R., 2020. The effect of rural credit on deforestation: evidence from the Brazilian Amazon. Econ. J. 130, 290-330. https:// doi.org/10.1093/ej/uez060.

Bäckstrand, K., 2008. Accountability of Networked Climate Governance: The Rise of Transnational Climate Partnerships. Global Environmental Politics 8 (3), 74-102.

Bager, S., Persson, U.M., Reis, T.N.P., 2020. Reducing Commodity-Driven Tropical Deforestation: Political Feasibility and "Theories of Change" for EU Policy Options. SSRN Working Paper. https://papers.ssrn.com/sol3/papers.cfm?abstrac t id $=3624073$.

Bahar, N.H.A., Lo, M., Sanjaya, M., Van Vianen, J., Alexander, P., Ickowitz, A. Sunderland, T., 2020. Meeting the food security challenge for nine billion people in 2050: what impact on forests? Glob. Environ. Chang. 62, 102056.

Baland, J.-M., Platteau, J.-P., 1996. Halting Degradation of Natural Resources: Is there a Role for Rural Communities? Clarendon Press, Oxford.

Balint, P.J., Stewart, R.E., Desai, A., Walters, L.C., 2011. Wicked Environmental Problems: Managing Uncertainty and Conflict. Island Press, Washington, DC.

Bardhan, P., Dayton-Johnson, J., 2000. Heterogeneity and commons management. In: Paper Presented at the Proceedings of the 8th International Conference on Common Property. IASCP, Bloomington, Indiana.

Barkhordarian, A., Saatchi, S.S., Behrangi, A., Loikith, P.C., Mechoso, C.R., 2019. A recent systematic increase in vapor pressure deficit over tropical South America. Sci. Rep. 9 (1), 15331. https://doi.org/10.1038/s41598-019-51857-8.

Barrett, S., Dannenberg, A., 2014. Sensitivity of collective action to uncertainty about climate tipping points. Nat. Clim. Chang. 4, 36-39.

Bastos Lima, M.G., Persson, U.M., 2020. Commodity-centric landscape governance as a double-edged sword: the case of soy and the Cerrado working group in Brazil. Front. For. Glob. Chang. 3, 27.

Bastos Lima, M.G., Visseren-Hamakers, I.J., Braña Varela, J., Gupta, A., 2017. A reality check on the landscape approach to REDD+: lessons from Latin America. Forest Policy Econ. 78, 10-20.

Berkes, J, Folke, C, Colding, J, 2003. In: Berkes, J, Folke, C, Colding, J (Eds.), Navigating Social-Ecological Systems Building Resilience For Complexity And Change. Cambridge University Press.

Biel, A., Thøgersen, J., 2007. Activation of social norms in social dilemmas: A review of the evidence and reflections on the implications for environmental behaviour. J. Econ. Psychol. 28, 93-112. https://doi.org/10.1016/j.joep.2006.03. 003.

Biermann, F, 2012. Planetary boundaries and earth system governance: Exploring the links. Ecological Economics. https://doi.org/10.1016/j.ecolecon.2012.02.016.

Birdsall, N., Savedoff, W., Seymour, F., 2014. The Brazil-Norway agreement with performance-based payments for forest conservation: Successes, challenges, and lessons. In: CGD Climate and Forest Paper Series \#4. Center for Global Development, Washington DC.

Bisschop, L., 2012. Out of the woods: the illegal trade in tropical timber and a European trade hub. Glob. Crime 13, 191-212.

Börner, J., Wunder, S., Wertz-Kanounnikoff, S., Hyman, G., Nascimento, N., 2014. Forest law enforcement in the Brazilian Amazon: costs and income effects. Glob. Environ. Chang. 29, 294-305.

Boucher, D., Roquemore, S., Fitzhugh, E., 2013. Brazil's success in reducing deforestation. Trop. Conserv. Sci. 6 (3), 426-445.

Bouman, T., Verschoor, M., Albers, C.J., Böhm, G., Fisher, S.D., Poortinga, W., Steg, L., 2020. When worry about climate change leads to climate action: how values, worry and personal responsibility relate to various climate actions. Glob. Environ. Chang. 62, 102061.

Boyd, J.M., 1984. The role of religion in conservation. Environmentalist 4, 40-44.

Brienen, R.J., Phillips, O.L., Feldpausch, T.R., Gloor, E., Baker, T.R., Lloyd, J., Martinez, R.V., 2015. Long-term decline of the Amazon carbon sink. Nature 519 (7543), 344-348.

Buckley, K.J., Newton, P., Gibbs, H.K., McConnel, I., Ehrmann, I., 2019. Pursuing sustainability through multi-stakeholder collaboration: A description of the governance, actions, and perceived impacts of the roundtables for sustainable beef. World Dev. 121, 203-217. 
Carpenter, J.P., 2007. Punishing free-riders: how group size affects mutual monitoring and the provision of public goods. Game Econ. Behav. 60, 31-51. https://doi.org/ 10.1016/j.geb. 2006.08.011.

Castro-Nuñez, A., Mertz, O., Sosa, C.C., 2017. Geographic overlaps between priority areas for forest carbon-storage efforts and those for delivering peace building programs: implications for policy design. Environ. Res. Lett. 12, 054014.

Chen, S., 2018. Multinational corporate power, influence and responsibility in global supply chains. J. Bus. Ethics 148, 365-374.

Coe, M.T., Brando, P.M., Deegan, L.A., Macedo, M.N., Neill, C., Silvério, D.V., 2017. The forests of the Amazon and Cerrado moderate regional climate and are the key to the future. Trop. Conserv. Sci. 10 https://doi.org/10.1177/1940082917720671.

Cohn, A., 2017. Leveraging climate regulation by ecosystems for agriculture to promote ecosystem stewardship. Trop. Conserv. Sci. 10 https://doi.org/10.1177/ 1940082917720672.

Cohn, A.S., Mosnier, A., Havlík, P., Valin, H., Herrero, M., Schmid, E., Obersteiner, M., 2014. Cattle ranching intensification in Brazil can reduce global greenhouse gas emissions by sparing land from deforestation. Proc. Natl. Acad. Sci. 111, 7236-7241.

Coq-Huelva, D., Torres-Navarrete, B., Bueno-Suárez, C., 2018. Indigenous worldviews and Western conventions: Sumak Kawsay and cocoa production in Ecuadorian Amazonia. Agric. Hum. Values 35, 163-179.

Cortner, O., Garrett, R.D., Valentim, J.F., Ferreira, J., Niles, M.T., Reis, J., Gil, J., 2019. Perceptions of integrated crop-livestock systems for sustainable intensification in the Brazilian Amazon. Land Use Policy 82, 841-853.

Cossart, S., Chaplier, J., Beau de Lomenie, T., 2017. The French law on duty of care: A historic step towards making globalization work for all. Bus. Hum. Right J. 2, 317-323.

Dawes, R.M., 1980. Social dilemmas. Annu. Rev. Psychol. 31, 169-193.

De Schutter, O., 2017. The political economy of food systems reform. Eur. Rev. Agric. Econ. 44, 705-731. https://doi.org/10.1093/erae/jbx009.

DeFries, R., Nagendra, H., 2017. Ecosystem management as a wicked problem. Science 356, 265-270.

Dendler, L., 2014. Sustainability Meta labelling: an effective measure to facilitate more sustainable consumption and production? J. Clean. Prod. 63, 74-83.

DeSombre, E., 2018. Why Good People Do Bad Environmental Things. Oxford University Press, Oxford.

Dietz, T., Estrella Chong, A., Grabs, J., Kilian, B., 2020. How effective is multiple certification in improving the economic conditions of smallholder farmers? Evidence from an impact evaluation in Colombia's Coffee Belt. J. Dev. Stud. 56 (6), 1141-1160.

Escobar, N., Tizado, E.J., Zu Ermgassen, E.K., Löfgren, P., Börner, J., Godar, J., 2020. Spatially-explicit footprints of agricultural commodities: mapping carbon emissions embodied in Brazil's soy exports. Glob. Environ. Chang. 62, 102067.

Esquivel-Muelbert, A., Baker, T.R., Dexter, K.G., Lewis, S.L., Brienen, R.J.W., Feldpausch, T.R., Phillips, O.L., 2019. Compositional response of Amazon forests to climate change. Glob. Chang. Biol. 25 (1), 39-56. https://doi.org/10.1111/ gcb.14413.

Evans, K., Murphy, L., de Jong, W., 2014. Global versus local narratives of REDD: A case study from Peru's Amazon. Environ. Sci. Pol. 35, 98-108. https://doi.org/10.1016/j envsci.2012.12.013.

Fehr, E., Gächhter, S., 2002. Altruistic punishment in humans. Nature 415, 137-140.

Fehr, E., Gächter, S., 2000. Cooperation and punishment in public goods experiments. Am. Econ. Rev. 90, 980-994.

Fehr, E., Schmidt, K.M., 1999. A theory of fairness, competition, and cooperation. Q. J. Econ. 114, 817-868.

Feldpausch, T.R., Phillips, O.L., Brienen, R.J.W., Gloor, E., Lloyd, J., Lopez-Gonzalez, G. Alvarez-Loayza, P., 2016. Amazon forest response to repeated droughts. Glob. Biogeochem. Cycles 30 (7), 964-982.

Fischer, H., Amelung, D., Said, N., 2019. The accuracy of German citizens' confidence in their climate change knowledge. Nat. Clim. Chang. 9, 776-780.

Forstater, M., Nakhooda, S., Watson, C., 2013. The effectiveness of climate finance: A review of the Amazon fund. In: ODI Working Paper 372. https://www.odi.org/sites/ odi.org.uk/files/odi-assets/publications-opinion-files/8340.pdf.

Furumo, P.R., Lambin, E.F., 2020. Scaling up zero-deforestation initiatives through public-private partnerships: A look inside post-conflict Colombia. Glob. Environ. Chang. 62, 102055.

Gächter, S., Fehr, E., 1999. Collective action as a social exchange. J. Econ. Behav. Organ. 39, 341-369.

Gächter, S., Herrmann, B., 2009. Reciprocity, culture and human cooperation: previous insights and a new cross-cultural experiment. Philos. Trans. Royal Soc. B: Biol. Sci. 364, 791-806.

Galaz, V., Biermann, F., Crona, B., Loorbach, D., Folke, C., Olsson, P., Nilsson, M., Allouche, J., Persson, A., Reischl, G., 2012. 'Planetary boundaries'-exploring the challenges for global environmental governance. Curr. Opin. Environ. Sustain. 4 (1), 80-87.

Galaz, V., Crona, B., Dauriach, A., Jouffray, J.-B., Österblom, H., Fichtner, J., 2018a. Tax havens and global environmental degradation. Nat. Ecol. Evol. 2, 1352-1357. https://doi.org/10.1038/s41559-018-0497-3.

Galaz, V., Crona, B., Dauriach, A., Scholtens, B., Steffen, W., 2018b. Finance and the earth system: exploring the links between financial actors and non-linear changes in the climate system. Glob. Environ. Chang. 53, 296-302. https://doi.org/10.1016/j. gloenvcha.2018.09.008.

Gardner, T.A., Benzie, M., Börner, J., Dawkins, E., Fick, S., Garrett, R., Mardas, N., 2019. Transparency and sustainability in global commodity supply chains. World Dev. 121 163-177.
Garrett, R.D., Levy, S., Carlson, K.M., Gardner, T.A., Godar, J., Clapp, J., Barr, R., 2019. Criteria for effective zero-deforestation commitments. Glob. Environ. Chang. 54, 135-147.

Gibbs, H.K., Rausch, L., Munger, J., Schelly, I., Morton, D.C., Noojipady, P., Walker, N.F., 2015. Brazil's Soy Moratorium. Science 347, 377-378. https://doi.org/10.1126/ science.aaa0181.

Gibbs, H.K., Munger, J., Roe, J.L., Barreto, P., Pereira, R., Christie, M., Walker, N.F., 2016. Did ranchers and slaughterhouses respond to zero-deforestation agreements in the Brazilian Amazon? Conserv. Lett. 9, 32-42.

Gifford, R., 2011. The dragons of inaction: Psychological barriers that limit climate change mitigation and adaptation. American Psychologist 66 (4), 290-302.

Greif, A., 1993. Contract enforceability and economic institutions in early trade: the Maghribi traders' coalition. Am. Econ. Rev. 83, 525-548.

Gupta, A., Van Asselt, H., 2019. Transparency in multilateral climate politics: furthering (or distracting from) accountability? Regul. Govern. 13, 18-34.

Hardin, G., 2009. The tragedy of the commons. J. Nat. Resour. Pol. Res. 1 (3), 243-253.

Hecht, S.B., 2011. The new Amazon geographies: insurgent citizenship, "Amazon Nation" and the politics of environmentalisms. J. Cult. Geogr. 28 (1), 203-223.

Henders, S., Persson, U.M., Kastner, T., 2015. Trading forests: land-use change and carbon emissions embodied in production and exports of forest-risk commodities. Environ. Res. Lett. 10, 125012.

IPCC (Intergovernmental Panel on Climate Change), 2018. Special Report on Global Warming of $1.5^{\circ} \mathrm{C}$. http://ipcc.ch/report/sr15/.

Isaac, R.M., Walker, J.M., Williams, A.W., 1994. Group size and the voluntary provision of public goods: experimental evidence utilizing large groups. J. Public Econ. 54, $1-36$.

Jagers, S.C., Harring, N., Löfgren, A., Sjöstedt, M., Alpizar, F., Brülde, B., Steffen, W., 2020. On the preconditions for large-scale collective action. Ambio 49 (7), 1282-1296.

Jamieson, D., 2017. Reason in a Dark Time: Why the Struggle against Climate Change Failed-And What it Means for our Future. Oxford University Press, Oxford.

Janssen, D., Langen, N., 2017. The bunch of sustainability labels: do consumers differentiate? J. Clean. Prod. 143, 1233-1245.

Kerr, N.L., 1995. Norms in social dilemmas. In: Schroeder, D. (Ed.), Social Dilemmas: Social Psychological Perspectives. Pergamon Press, New York, pp. 31-47.

Keser, C., Van Winden, F., 2000. Conditional cooperation and voluntary contributions to public goods. Scand. J. Econ. 102, 23-39.

Kocher, M.G., Cherry, T., Kroll, S., Netzer, R.J., Sutter, M., 2008. Conditional cooperation on three continents. Econ. Lett. 101 (3), 175-178.

Kolk, A., 1998. From conflict to cooperation: international policies to protect the Brazilian Amazon. World Dev. 26, 1481-1493. https://doi.org/10.1016/S0305750X(98)00062-X.

Kollmuss, A., Agyeman, J., 2002. Mind the Gap: Why do people act environmentally and what are the barriers to pro-environmental behavior? Environmental Education Research 8 (3), 239-260.

Ladle, R.J., Malhado, A.C.M., Todd, P.A., Malhado, A.C.M., 2010. Perceptions of Amazonian deforestation in the British and Brazilian media. Acta Amazon. 40 (2), 319-324.

Lahsen, M., 2017. Buffers against inconvenient knowledge: Brazilian newspaper representations of the climate-meat link. Desenvolvimento e Meio Ambiente 40, $17-35$.

Lambin, E.F., Gibbs, H.K., Heilmayr, R., Carlson, K.M., Fleck, L.C., Garrett, R.D., Nolte, C., 2018. The role of supply-chain initiatives in reducing deforestation. Nat. Clim. Chang. 8 (2), 109-116.

Laury, S.K., Walker, J.M., Williams, A.W., 1995. Anonymity and the voluntary provision of public goods. J. Econ. Behav. Organ. 27, 365-380.

Leite-Filho, A.T., Costa, M.H., Fu, R., 2020. The southern Amazon rainy season: the role of deforestation and its interactions with large-scale mechanisms. Int. J. Climatol. 40 (4), 2328-2341. https://doi.org/10.1002/joc.6335.

Lenton, T.M., Held, H., Kriegler, E., Hall, J.W., Lucht, W., Rahmstorf, S., Schellnhuber, H. J., 2008. Tipping elements in Earth's climate system. Proc. Natl. Acad. Sci. 105, 1786-1793.

Lenton, T.M., Rockström, J., Gaffney, O., Rahmstorf, S., Richardson, K., Steffen, W., Schellnhuber, H.J., 2019. Climate tipping points: too risky to bet against. Nature 575, 593-596.

Levi, M., 1998. A state of trust. In: Braithwaite, V., Levi, M. (Eds.), Trust and Governance. Russell Sage Foundation, New York, pp. 77-101.

Levi, M., 2006. Why we need a new theory of government. Perspect. Polit. 4 (1), 5-19.

London, M., Kelly, B., 2007. The Last Forest: The Amazon in the Age of Globalization. Random House, New York.

Lovejoy, T.E., Nobre, C., 2018. Amazon tipping point. Sci. Adv. 4 (2) eaat2340.

Lovejoy, T.E., Nobre, C., 2019. Amazon tipping point: last chance for action. Sci. Adv. 5 (12) https://doi.org/10.1126/sciadv.aba2949 eaba2949.

Mammadova, A., Maslero, M., Pettenella, D., 2020. Embedded deforestation: the case study of the Brazilian-Italian bovine leather trade. Forests 11, 472.

Mansbridge, J., 2014. The role of the state in governing the commons. Environ. Sci. Pol. 36, 8-10. https://doi.org/10.1016/j.envsci.2013.07.006.

MapBiomas, 2020. Annual Deforestation Report of Brazil 2019. http://alerta.mapbioma s.org (accessed 3 July 2020).

Mason, M., 2008. The governance of transnational environmental harm: addressing new modes of accountability/responsibility. Glob. Environmen. Polit. 8 (3), 8-24.

McDonald, R.I., Chai, H.Y., Newell, B.R., 2015. Personal experience and the 'psychological distance' of climate change: an integrative review. J. Environ. Psychol. 44, 109-118. 
Mercure, J.F., Paim, M.A., Bocquillon, P., Lindner, S., Salas, P., Martinelli, P., Ribeiro, J. M.P., 2019. System complexity and policy integration challenges: the Brazilian energy-water-food nexus. Renew. Sust. Energ. Rev. 105, 230-243.

Messick, D.M., Wilke, H., Brewer, M.B., Kramer, R.M., Zemke, P.E., Lui, L., 1983. Individual adaptations and structural change as solutions to social dilemmas. J. Pers. Soc. Psychol. 44, 294-309.

Moran, E.F., 1993. Deforestation and land use in the Brazilian Amazon. Hum. Ecol. 21 (1), 1-21.

Nepstad, D., McGrath, D., Stickler, C., Alencar, A., Azevedo, A., Swette, B., da Motta, R. S., 2014. Slowing Amazon deforestation through public policy and interventions in beef and soy supply chains. Science 344 (6188), 1118-1123.

Newton, P., Benzeev, R., 2018. The role of zero-deforestation commitments in protecting and enhancing rural livelihoods. Curr. Opin. Environ. Sustain. 32, 126-133.

Nobre, C.A., Sampaio, G., Borma, L.S., Castilla-Rubio, J.C., Silva, J.S., Cardoso, M., 2016. Land-use and climate change risks in the Amazon and the need of a novel sustainable development paradigm. Proc. Natl. Acad. Sci. 113, 10759-10768.

Obradovich, N., Guenther, S.M., 2016. Collective responsibility amplifies mitigation behaviors. Clim. Chang. 137, 307-319.

Oliveira, L.J.C., Costa, M.H., Soares-Filho, B.S., Coe, M.T., 2013. Large-scale expansion of agriculture in Amazonia may be a no-win scenario. Environ. Res. Lett. 8, 024021 https://doi.org/10.1088/1748-9326/8/2/024021.

Orr, D.W., 1990. Environmental education and ecological literacy. Educ. Dig. 55, 49-53.

Ostrom, E., 1990. Governing the Commons: The Evolution of Institutions for Collective Action. Cambridge University Press, Cambridge.

Ostrom, E., 1998. A behavioral approach to the rational choice theory of collective action. Am. Polit. Sci. Rev. 92, 1-22.

Ostrom, E., 2010. Polycentric systems for coping with collective action and global environmental change. Glob. Environ. Chang. 20, 550-557. https://doi.org/ 10.1016/j.gloenvcha.2010. 07.004.

Ostrom, E., Walker, J., Gardner, R., 1992. Covenants With and Without a Sword: SelfGovernance is Possible. American Political Science Review 86 (2), 404-417.

Pendrill, F., Persson, U.M., Godar, J., Kastner, T., Moran, D., Schmidt, S., Wood, R., 2019. Agricultural and forestry trade drives large share of tropical deforestation emissions. Glob. Environ. Chang. 56, 1-10. https://doi.org/10.1016/j.gloenvcha.2019.03.002.

Pereira, J.C., Viola, E., 2019. Catastrophic climate risk and brazilian amazonian politics and policies: A new research agenda. Glob. Environmen. Polit. 19 (2), 93-103.

Piotrowski, M., 2019. Nearing the tipping point: Drivers of deforestation in the Amazon Region. In: Inter-American Dialogue. https://www.thedialogue.org/analysis/nearin $\mathrm{g}$-the-tipping-point-drivers-of-deforestation-in-the-amazon-region/ (accessed XXXX).

Rapoport, A., Budescu, D.V., Suleiman, R., Weg, E., 1992. Social dilemmas with uniformly distributed resources. In: Liebrand, W.B.G., Messick, D.M., Wilke, H.A.M. (Eds.), Social Dilem- Mas: Theoretical Issues and Research Findings. Pergamon Press, Elmsford, pp. 43-57.

Reid, E.M., Toffel, M.W., 2009. Responding to public and private politics: corporate disclosure of climate change strategies. Strateg. Manag. J. 30, 1157-1178. https:// doi.org/10.1002/smj.796.

Rothstein, B., 2005. Social Traps and the Problem of Trust. Cambridge University Press.

Rothstein, B., Eek, D., 2009. Political corruption and social trust: an experimental approach. Ration. Soc. 21, 81-112. https://doi.org/10.1177/1043463108099349.

Rothstein, B., Stolle, D., 2008. The state and social capital: an institutional theory of generalized trust. Comp. Polit. 40, 441-459.

Saberi, S., Kouhizadeh, M., Sarkis, J., Shen, L., 2019. Blockchain technology and its relationships to sustainable supply chain management. Int. J. Prod. Res. 57 (7), 2117-2135.

Scheffer, M, et al., 2009. Early-warning signals for critical transitions. Nature 461, 53-59. https://doi.org/10.1038/nature08227.

Scheidel, A., Del Bene, D., Liu, J., Martinez-Alier, J., 2020. Environmental conflicts and defenders: A global overview. Glob. Environ. Chang. 63, 102104.
Setzer, A., 2019. Resumo do Evento da Tarde Escura em São Paulo, 20/Agosto/2019 e sua Relação com as Nuvens das Queimadas. https://www.oeco.org.br/wp-content /uploads/2019/08/EventoNuvemEscuridaoFumaca_SaoPaulo_SP-1.pdf.

Siegel, K., Bastos Lima, M.G., 2020. When international sustainability frameworks encounter domestic politics: the sustainable development goals and agri-food governance in South-America. World Dev. 135.

Snyder, P.K., 2010. The influence of tropical deforestation on the northern hemisphere climate by atmospheric teleconnections. Earth Interact. 14 (4), 1-34.

Soares-Filho, B., Rajão, R., Macedo, M., Carneiro, A., Costa, W., Coe, M., Alencar, A., 2014. Cracking Brazil's Forest Code, 344(6182), pp. 363-364.

Sonter, L.J., Herrera, D., Barrett, D.J., Galford, G.L., Moran, C.J., Soares-Filho, B.S., 2017. Mining drives extensive deforestation in the Brazilian Amazon. Nat. Commun. 8, 1013. https://doi.org/10.1038/s41467-017-00557-w.

Stabile, M.C., Guimarães, A.L., Silva, D.S., Ribeiro, V., Macedo, M.N., Coe, M.T., Alencar, A., 2020. Solving Brazil's land use puzzle: increasing production and slowing Amazon deforestation. Land Use Policy 91, 104362.

Steffen, Will, Rockström, J, Richardson, K, Lenton, T.M., Folke, C, Liverman, D, Summerhayes, C.P., et al., 2018. Trajectories of the Earth System in the Anthropocene. Proceedings of the National Academy of Sciences. https://doi.org/ 10.1073/pnas.1810141115.

Stern, P.C., Dietz, T., Abel, T., Guagnano, G.A., Kalof, L., 1999. A value-belief-norm theory of support for social movements: the case of environmentalism. Hum. Ecol. Rev. 6, 81-97.

Strassburg, B.B.N., Latawiec, A.E., Barioni, L.G., Nobre, C.A., da Silva, V.P., Valentim, J. F., Assad, E.D., 2014. When enough should be enough: improving the use of current agricultural lands could meet production demands and spare natural habitats in Brazil. Glob. Environ. Chang. 28, 84-97. https://doi.org/10.1016/j. gloenvcha.2014.06.001.

Sutinen, J.G., Kuperan, K., 1999. A socio-economic theory of regulatory compliance. Int. J. Soc. Econ. 26, 174-193.

Trase, 2018. Trase Yearbook 2018: Sustainability in Forest-Risk Supply Chains Spotlight on Brazilian Soy. Available online at. http://yearbook2018.trase.earth (accessed September 02, 2020).

Trope, Y., Liberman, N., 2010. Construal-level theory of psychological distance. Psychol. Rev. 117 (2), 440.

Tyler, T.R., 2010. Why People Cooperate: The Role of Social Motivations. Princeton University Press, Princeton.

Uslaner, E.M., Brown, M., 2005. Inequality, trust, and civic engagement. Am. Politics Res. 33, 868-894.

Varughese, G., Ostrom, E., 2001. The contested role of heterogeneity in collective action: some evidence from com- munity forestry in Nepal. World Dev. 29, 747-765.

Werth, D., Avissar, R., 2004. The regional evapotranspiration of the Amazon. J. Hydrometeorol. 5 (1), 100-109.

Wilke, H.A.M., 1991. Greed, efficiency and fairness in resource management situations. Eur. Rev. Soc. Psychol. 2, 165-187. https://doi.org/10.1080/14792779143000051.

Wilson, E.O., 2017. Biophilia and the conservation ethic. In: Mysterud, I. (Ed.), Evolutionary Perspectives on Environmental Problems. Routledge, Oxon, pp. 249-258.

Wit, A., Wilke, H., 1998. Public good provision under environmental and social uncertainty. Eur. J. Soc. Psychol. 28, 249-256.

Wuyts, B., Champneys, A.R., House, J.I., 2017. Amazonian forest-savanna bistability and human impact. Nat. Commun. 8, 15519.

Zu Ermgassen, E.K.H.J., Godar, J., Lathuillière, M.J., Löfgren, P., Gardner, T., Vasconcelos, A., Meyfroidt, P., 2020a. The origin, supply chain, and deforestation risk of Brazil's beef exports. Proc. Natl. Acad. Sci. 117 (50), 31770-31779. https:// doi.org/10.1073/pnas.2003270117.

Zu Ermgassen, E.K., Ayre, B., Godar, J., Lima, M.G.B., Bauch, S., Garrett, R., Meyfroidt, P., 2020b. Using supply chain data to monitor zero deforestation commitments: an assessment of progress in the Brazilian soy sector. Environ. Res. Lett. 15 (3), 035003. 